\title{
Testing the Validity of the Triplet Deficit Hypothesis for Turkey: Asymmetric Causality Analysis
}

\author{
Yusuf Ekrem AKBAŞ ${ }^{*}$, Fuat LEBE ${ }^{* *}$, Fatma ZEREN ${ }^{* * *}$
}

\begin{abstract}
In this study, the validity was analyzed of the triple deficit hypothesis in Turkey between the years 1960 and 2012. First, the stationarity of positive and negative shocks related to the current account deficit, budget deficit, and savings gap was tested. As a result of unit root tests, it was concluded that all the positive and negative shocks were I(1). Then, the causal relationship was analyzed with regard to the aforesaid shocks of variables by means of an asymmetric causality test. As a result of the asymmetric causality test, bi-directional causality was found between the current account deficit and the budget deficit and between the current account deficit and savings gap. Therefore, it can be concluded that the triple deficit hypothesis is valid in Turkey.
\end{abstract}

Keywords: Triplet Deficit, Current Account Balance, Budget, Saving-Investment, Asymmetric Causality

JEL Code Classification: F32, H62, O16, C32, F41

\footnotetext{
${ }^{*}$ Assist. Prof. Dr. in Economics, Adıyaman University, Adiyaman, Turkey. E-mail: akbasyea@gmail.com **Assist. Prof. Dr. in Economics, Adıyaman University, Adiyaman, Turkey. E-mail: flebe@adiyaman.edu.tr ${ }^{* * *}$ Assist. Prof. Dr. in Econometrics, Inonu University, Malatya, Turkey. E-mail: fatma.zeren@inonu.edu.tr
} 


\section{Introduction}

Recently, intensive studies have been conducted on the problems of the current account deficits and budget deficits which emerged in developed countries starting in the 1980s when globalization movements started to gain speed in the world economy and gradually spread to emerging countries. It is possible to group the conducted studies around two approaches. The first of these is the 'traditional (Keynesian) approach', which states that there is a positive relationship between the budget deficit and the current account deficit of a given country and the direction of this relationship is from budget deficit to current account deficit. According to this approach, in an economy where a flexible exchange rate is adopted, there will be a decrease in the aggregate savings of the country in the event that the taxes collected are less than public expenditures. Such a situation will first cause the national interest rates of the country to increase and afterwards to exceed the global average interest rate. The increase in the national interest rate will lead to an inflow of high amounts of foreign capital into the country and cause an increase in the value of the domestic currency. For this reason, while exports will become more expensive, imports will become cheaper. As a result, net exports will decrease and a current account deficit will be experienced (Froyen, 1999: 396). Economists who hold the traditional view explain this relationship as the 'twin deficit hypothesis'.

The second approach is the 'Ricardian Equivalence Hypothesis' (REH), which argues that there is no interaction between the current account deficit and the budget deficit of a given country. REH states that while public expenditures are constant the financing of budget deficits that may result from a decrease in taxes through borrowing will not have any effects on private sector expenditures. In this case, the action is only shifting the timing of tax collection from the current period to future periods (Vamvoukas, 1999: 1094). Since individuals know that a decrease in the tax revenues of the state will be compensated by a future loan or an increase in taxes, they know that current liabilities will be repaid through tax increases in the future, even though the state prefers loans. Therefore, the budget deficits that occur because of public borrowings or tax reductions will not have an increasing effect on private consumption behavior (assuming that public expenditures do not change). Considering that total domestic savings are composed of the sum of private sector and public sector savings, the decreasing of taxes by the state will also decrease public sector savings, but will increase private sector savings (Barro, 1989: 39). In parallel to the decrease in public sector savings, an increase in the savings of individuals will also cause an increase in savings that equals the budget deficit financed by the state. As a result of the increase in private savings, there will be no need for a foreign capital inflow into the country and a current accounts deficit will be out of the question (Khalid and Guan, 1999: 390). For this reason, this hypothesis, which was first stated by D. Ricardo and developed by R. Barro, asserts 
that there is no relationship between the budget deficit and the current account deficit of a given country.

It is concluded that the traditional approach was valid in some studies about twin deficits in the literature (Zietz and Pemberton, 1990; Rosensweig and Tallman, 1993; Dibooglu, 1997; Fidrmuc, 2003; Pattichis, 2004; Corsetti and Müller, 2006; Mukhtar et al., 2007; Ito, 2009; Ganchev, 2010; Iram, et al. 2011; Trachanas and Katrakilidis, 2013). However, the findings of several other studies support the REH (Dewald and Ulan, 1990; Kim, 1995; Kaufmann et al. 2002; Kim and Roubini, 2008; Ratha, 2012). Yet, some studies have also cast doubts on the validity of both traditional and REH approaches and have argued that the savings-investment gap is effective in the emergence of a current account deficit (Milesi-Ferretti and Razin, 1996; Higgins and Klitgaard, 1998; Cooper, 2001; Gale and Orszag, 2003; Freund, 2005; Hubbard, 2006; Kuijs, 2006; Gruber and Kamin, 2007). Although there was a budget surplus in some developed countries, growing current account deficits cast doubts on the validity of the twin deficit hypothesis.

With the liberalization of capital movements worldwide, the necessity that domestic investments be limited to the amount of domestic savings disappeared. When domestic investments are greater than domestic savings, the financing of the emergent savings-investment gap from abroad causes the savings-investment balance to play a role, along with the budget deficit, in the emergence of a current accounts deficit. This means that the budget balance, savings-investment balance, and current accounts balance of a country are all in deficit. Such a scenario is known as the 'triple deficit hypothesis' in the literature.

Knowing whether the twin or triple deficit hypothesis is valid for a country is highly important for policy selection. If policymakers know which hypothesis is valid for the economy of a given country, they can make better decisions to deal with a budget deficit, going either for public borrowing or adjustment of tax rates. For this reason, the results of the studies testing which of the aforementioned hypotheses is valid are important when making decisions. In countries like Turkey, where macroeconomic imbalances are at serious levels, knowing whether the triple deficit hypothesis is valid and, if so, how and to what extent it occurs is important for the reasons mentioned above.

Studies conducted on the Turkish economy mainly focus on twin deficits, whereas the effect of the savings-investment balance on the formation of the current account balance (that is, the triple deficit) is ignored. We believe that our study will contribute to the literature in this respect. Moreover, the empirical studies about foreign literature conducted on a case of a triple deficit used common classical approaches ${ }^{1}$. However, different from existing empirical studies, the asymmetric

${ }^{1}$ Ordinary Least Squares (OLS), Autoregressive Distributed Lag Model (ARDL), Vector Auto Regressive (VAR) and their common classical Granger causality tests were used in the studies.

EJBE 2014, 7 (14) 
causality test developed by Hatemi-J (2012) was used in this study. In this respect, our study is a first in the literature.

This paper aims to test the validity of the triple deficit in the Turkish economy using an asymmetric causality test. In this context, our study consists of five sections. Section 2 presents the related literature. The methodology, including the data and the models used in the study, is presented in Section 3. Empirical findings and economic comments on these findings are given in Section 4. Finally, Section 5 presents the conclusion of the study, including policy recommendations.

\section{Literature Review and Theory}

National income equations have represented the theoretical basis of the relationship between the budget deficit and the current account deficit (Lipsey et al., 1999: 337). The theoretical basis of the relationship among the savings gap, budget deficit, and current account deficit can be obtained with reference to this national income equation. It is as follows:

$$
Y=C+I+G+(X-M)=C+S+T
$$

where $Y$ is national income, $C$ is consumption expenditures, $I$ is investment expenditures, $G$ is public expenditures, $X$ is goods and services exports, $M$ is goods and services imports, $S$ is savings, and $T$ is tax. In equation (1) leakages are equal to injections. Therefore, equation (1) can be shown as follows:

$$
1+G+X=S+T+M
$$

With the help of equation (2), the relationship among the budget deficit, current account deficit, and savings gap can be determined as follows:

$$
(X-M)=(S-I)+(T-G)
$$

Equation (3) shows that the sum of the budget balance and the saving-investment balance is equal to the current account balance. In other words, equation (3) can be written as follows:

Current account deficit $(C A)=$ Savings gap $(S A)+$ Budget deficit $(B A)$

Equation (4) established the theoretical basis of our study.

The sum of the two balances in which the right side of equation (4) shows the internal balance of economics and the left side of equation (4) also determines the external balance of economics. Namely, the internal balance and external balance of economics are equal to each other and means that the more internal balance has a deficit, the more external balance has a deficit (Eğilmez, 2006). In this context, an emerging savings gap since domestic savings are little than domestic investments cause the triple deficit (Szakolczai, 2006: 40). In other words, if the private sector savings-investment balance or public sector balance which is on the right side of equation (4) has a deficit and the current account balance 
accompanies this deficit, the twin deficit is valid in economics. If both of the internal economic balances have a deficit, the triple deficit is valid in economics.

The relationship between the budget deficit and current account deficit is the subject of many studies in the literature. These studies have tried to determine the direction of this relationship by using different methods for different countries or groups of countries. Since the budget balance and current account balance had a deficit in the U.S. economy in the 1980s, initial researches were shown that generally focus on the U.S. economy (Darrat, 1988; Miller and Russek, 1989; LatifZaman and Da Costa, 1990; Tallman and Rosensweig, 1991; Bahmani-Oskooee, 1992). However, similar studies also have been encountered for other countries. Studies focusing on current account deficits and budget deficits have obtained a variety of results. Prover findings to traditional opinion have been obtained in numerous studies (Bernheim, 1988; Zietz and Pemberton, 1990; Biswas et al., 1992; Rosensweig and Tallman, 1993; Dibooglu, 1997; Egwaikhide, 1999; Khalid and Guan, 1999; Vamvoukas, 1999; Piersanti, 2000; Kulkarni and Erickson, 2001; Leachman and Francis, 2002; Fidrmuc, 2003; Kouassi et al., 2004; Pattichis, 2004; Corsetti and Müller, 2006; Salvatore, 2006; Mukhtar et al., 2007; Lau and Tang, 2009; Ito, 2009; Ganchev, 2010; Holmes, 2011; Iram et al., 2011; Zamanzadeh and Mehrara, 2011; Kalou and Paleologou, 2012; Trachanas and Katrakilidis, 2013). These studies have emphasized that budget deficits have a major impact on current account deficits. Some studies also obtained prover results for the REH which stated no interaction or restricted interaction between the two deficits (Abell,1990; Enders and Lee, 1990; Dewald and Ulan, 1990; Kearney and Monadjemi, 1990; Boucher, 1991; Feldstein, 1992; Kim, 1995; Alkswani, 2000; Kaufmann et al., 2002; Erceg et al., 2005; Kim and Roubini, 2008; Ratha, 2012).

On the other hand, some studies have linked the principal cause of budget deficits to the savings gap and then they have found the deterioration of current account balance by extension this savings gap. In this respect, these studies have emphasized that both the traditional approach and the REH approach cannot be accepted directly and that the relationship between the budget deficit and current account deficit is complicated. Namely, these studies have found that the twin deficit hypothesis is of doubtful and mainly reached conclusions which support the triple deficit hypothesis. However, studies which try to prove the triple deficit hypothesis are mainly theoretical in nature. For example, the studies of Hatsopoulos et al. (1988), Fischer and Easterly (1990), Hakkio (1995), Milesi-Ferretti and Razin (1996), Higgins and Klitgaard (1998), Cooper (2001), Mann (2002), Gale and Orszag (2003), Labonte (2005), Hubbard (2006), Szakolczai (2006), Elwell (2007, 2010) and Feldstein (2008) can be adduced for the theoretical studies about triplet deficit. Some empirical studies on this topic have argued that the triple deficit hypothesis is valid (Zaidi, 1985; Roubini, 1988; Baxter and Crucini, 1993; Eisner, 1994; Freund, 2005; Kuijs, 2006; Gruber and Kamin, 2007). For example, Penati and Dooley (1984), in their study of 19 industrialized countries, demonstrated the 
validity of the triple deficit hypothesis which emphasizes that imbalances emerge in the current account because of changes in the volume of savings.

In a study on developing countries, Zaidi (1985) found that the expansion of investment expenditures would put pressure on saving rates and thus cause an increase in budget deficits and have a negative effect on external deficits.

Dooley et al. (1987) analyzed data from developed and emerging countries for the period of 1960-1984 through OLS analysis. The results of the analysis showed that it was necessary, especially for emerging countries, to finance current account imbalances that occur as a result of savings gaps through resources in the form of credits and grants. Moreover, the authors emphasize that a decrease in current account deficits depended on increases in savings rates. In a study of 18 member states of the Organization for Economic Cooperation and Development (OECD) for the period 1960-1985, Roubini (1988) determined that savings gaps and the budget deficits that occur as a result had increasing effects on external deficits. Baxter and Crucini (1993) analyzed the data from eight developed countries for the period 1960-1985 and found that the savings-investment relationship was stronger in developed countries compared to underdeveloped and developing countries and that increases that occur in investment volume increase current account deficits. Eisner (1994) conducted a VAR analysis on data from the US for the period 19721991. He argued that a decrease in public expenditures increases the savings of the public sector and therefore shrinks budget deficits. Furthermore, he attributed foreign trade deficits to increasing public expenditures and the budget deficits that emerge as a result and concluded that the triple deficit hypothesis was valid for the US. In a study of data from 25 industrialized countries for the period 1970-1997, Freund (2005) stated that a reduction in investment expenditures could reverse current account deficits by causing an increase in investment rates. Kuijs (2006) analyzed data for the period 1980-2005 and found that the triple deficit hypothesis applied in reverse to the Chinese economy and called this a case of triple surpluses'. In their study of 61 countries for the period 1982-2003, Gruber and Kamin (2007) stated that globally increasing savings negatively affected economies that experienced a savings gap and thus caused an increase in the current accounts deficit.

Alongside the empirical studies which prove the validity of the triple deficit hypothesis, there are also empirical studies which show that there is a limited relationship or no causality between the aforementioned variables (Bachman, 1992; Winner, 1993; Domenech et al., 2000). For example, in a VAR analysis of data from the US for the period 1974-1988, Bachman (1992) stated that budget deficits had an effect on current account deficits and emphasized that changes that occurred in investment volume were not significant enough to explain current account deficits. Furthermore, he argued that the twin deficits hypothesis was valid for the US economy, but that it was not possible to obtain a clear result regarding triple deficits. Winner (1993) conducted a study of the economy of Australia 
through the OLS approach and found that REH was valid for the country. In addition, he also found that budget deficits rather than savings gaps were caused by different macroeconomic factors and therefore it was difficult to state that current account deficits occurred due to budget deficits. In a structural VAR analysis of the data from 18 OECD countries for the period 1962-1994, Domenech et al. (2000) stated that the primary reason for budget deficits was not savings gaps and that REH was valid for the countries in question.

There are no empirical studies regarding the triple deficit hypothesis that have been conducted with regard to the Turkish economy. However, there are a lot of studies focus on twin deficits. For example, in their studies, Zengin (2000), Kutlar and Şimşek (2001), Akbostancı and Tunç (2002), Ata and Yücel (2003), Utkulu (2003), Ay et al. (2004), Yaldız (2006), Acaravcı and Öztürk (2008), Erdinç (2008), Uz (2010) and Altıntaş and Taban (2011) obtained findings that confirm the traditional approach. Furthermore, there are also studies that support REH for the Turkish economy (Bilgili and Bilgili, 1998; Kuştepeli, 2001; Aksu and Başar, 2005, 2009).

\section{Data and Methodology}

In this study, the validity of the triple deficit hypothesis in Turkey was analyzed. The analysis covered annual data for the period 1960-2012. The original values are used in the econometric analysis. Moreover, the data was evaluated as a percentage of gross domestic product (GDP). The data used in the study are as follows:

\section{CA: Current account deficit (\% GDP)}

\section{$B A$ : Budget deficit (\% GDP)}

$S A$ : Savings gap (\% GDP)

The $C A$ and $S A$ series were obtained from the electronic database of the World Development Indicator (WDI), a World Bank electronic database. The BA series was also obtained from the OECD statistical database.

Firstly, the stationarity of positive and negative shocks was tested in this study. Then, an asymmetric causality test was carried out to determine whether there was a causal relationship among the shocks.

\subsection{Asymmetric Causality Test}

This test developed by Hatemi-J (HJ) is based on the Toda-Yamamoto (TY) (1995) causality test. Tests for a unit root and cointegration in the economic time series and the estimation of the cointegrating vector are required before causality tests based on Granger causality can be conducted. It is not necessary that series be stationary at level and cointegrated for the TY test. The TY test is based on the estimation of the $\operatorname{VAR}\left(p+d_{\max }\right)$ process in which $p$ is the optimal lag length and $d_{\max }$ is the maximum order of stationarity. Series are not required to be stationary at level and cointegrated for the HJ test as in the TY test. Unlike the TY test, HJ has a bootstrap distribution. Moreover, the effects of positive and negative shocks can 
be analyzed in the $\mathrm{HJ}$ test. In this regard, the $\mathrm{HJ}$ test differs from the TY and causality tests developed by Hacker and Hatemi-J (2006, 2010).Moreover, the HJ test also calculates the causal parameters (Hatemi-J and Uddin, 2012: 465).Given that the current account deficit; denoted by CA, the budget deficit; denoted by BA, as well as the net savings gap; denoted by $S A$, are integrated variables, each can be defined as a random walk process, as follows:

$B A_{t}=B A_{t-1}+\varepsilon_{1 t}=B A_{0}+\sum_{i=1}^{t} \varepsilon_{1 i}$

and

$$
\begin{aligned}
& S A_{t}=S A_{t-1}+\varepsilon_{1 t}=S A_{0}+\sum_{i=1}^{t} \varepsilon_{1 i}, \\
& C A_{t}=C A_{t-1}+\varepsilon_{2 t}=C A_{0}+\sum_{i=1}^{t} \varepsilon_{2 i,}
\end{aligned}
$$

where $t=1,2, \ldots, T$. The constants $X_{0}$ and $Y_{0}$ are the initial values, and the variables $\varepsilon_{1 i}$, and $\varepsilon_{2 i}$, indicate white noise error terms. Positive and negative shocks can be identified as the following, respectively:

$\varepsilon_{1 i}^{+}=\max \left(\varepsilon_{1 i}, 0\right), \varepsilon_{2 i}^{+}=\max \left(\varepsilon_{2 i}, 0\right), \varepsilon_{2 i}^{-}=\min \left(\varepsilon_{1 i}, 0\right)$ and $\varepsilon_{2 i}^{-}=\min \left(\varepsilon_{2 i}, 0\right)$.

Therefore, $\varepsilon_{1 i}$, and $\varepsilon_{2 i}$, can be defined as follows:

$\varepsilon_{1 i}=\varepsilon_{1 i}^{+}+\varepsilon_{1 i}^{-}$and $\varepsilon_{2 i}=\varepsilon_{2 i}^{+}+\varepsilon_{2 i}^{-}$. It follows that

$B A_{t}=B A_{t-1}+\varepsilon_{1 t}=B A_{0}+\sum_{i=1}^{t} \varepsilon_{1 i}^{+}+\sum_{i=1}^{t} \varepsilon_{1 i}^{-}$

$S A_{t}=S A_{t-1}+\varepsilon_{1 t}=S A_{0}+\sum_{i=1}^{t} \varepsilon_{1 i}^{+}+\sum_{i=1}^{t} \varepsilon_{1 i}^{-}$

and likewise

$C A_{t}=C A_{t-1}+\varepsilon_{2 t}=C A_{0}+\sum_{i=1}^{t} \varepsilon_{2 i}^{+}+\sum_{i=1}^{t} \varepsilon_{2 i}^{-}$

Finally, the positive and negative shocks of each variable can be defined in a cumulative form as follows:

$$
\begin{aligned}
& B A_{t}^{+}=\sum_{i=1}^{t} \varepsilon_{1 i}^{+}, B A_{t}^{-}=\sum_{i=1}^{t} \varepsilon_{1 i}^{-} \\
& S A_{t}^{+}=\sum_{i=1}^{t} \varepsilon_{1 i}^{+}, S A_{t}^{-}=\sum_{i=1}^{t} \varepsilon_{1 i}^{-} \\
& C A_{t}^{+}=\sum_{i=1}^{t} \varepsilon_{2 i}^{+}, C A_{t}^{-}=\sum_{i=1}^{t} \varepsilon_{2 i}^{-}
\end{aligned}
$$


where the impact of each negative and positive shock on the relevant variable is permanent. These phases can be used to test for asymmetric causality between the variables.

\section{Empirical Results}

Before asymmetric causality analysis can be applied, it is necessary to determine the order of stationarity of series shocks related to the three aforementioned variables. In this context, the results of the unit root test for series are shown in Table 1.

\section{Table 1: The Results of Unit Root Tests}

\begin{tabular}{c|cc|cc}
\hline \multirow{2}{*}{ Variables } & \multicolumn{2}{|c|}{ Level } & \multicolumn{2}{c}{ First Difference } \\
\cline { 2 - 5 } & $\begin{array}{c}\text { Augmented } \\
\text { Dickey Fuller }\end{array}$ & $\begin{array}{c}\text { Phillips Perron } \\
\text { Augmented }\end{array}$ & $\begin{array}{c}\text { Dickey Fuller } \\
\text { Phillips Perron }\end{array}$ \\
\hline$B A^{-}$ & 0.96 & 0.97 & 0.00 & 0.00 \\
$C A^{-}$ & 0.98 & 0.99 & 0.00 & 0.00 \\
$S A^{-}$ & 0.92 & 0.95 & 0.00 & 0.00 \\
$B A^{+}$ & 0.99 & 0.99 & 0.00 & 0.00 \\
$C A^{+}$ & 0.91 & 0.94 & 0.00 & 0.00 \\
$S A^{+}$ & 0.76 & 0.76 & 0.00 & 0.00 \\
\hline
\end{tabular}

Note: $p$-values were shown in table.

As shown in Table 1, the positive and negative series shocks are not stationary at level. Order of stationarity for these shocks are /(1). After determining the order of stationarity of positive and negative shocks, an asymmetric causality test can be applied. The results of this asymmetric test are presented in Table 2.

Table 2: The Results of Asymmetric Causality Test

\begin{tabular}{lccccc}
\hline $\begin{array}{c}\text { Null } \\
\text { hypothesis }\end{array}$ & Test value & $\begin{array}{c}\text { Bootstrap } \\
\text { CV at \%1 }\end{array}$ & $\begin{array}{c}\text { Bootstrap } \\
\text { CV at \%5 }\end{array}$ & $\begin{array}{c}\text { Bootstrap } \\
\text { CV at \%10 }\end{array}$ & Optimal Lag \\
\hline $\mathrm{BA}^{+} \nRightarrow \mathrm{CA}^{+}$ & 0.12 & 10.00 & 5.46 & 3.36 & 1 \\
$\mathrm{BA}^{-} \nRightarrow \mathrm{CA}^{-}$ & $6.87^{* *}$ & 7.75 & 3.57 & 2.53 & 1 \\
$\mathrm{SA}^{+} \nRightarrow \mathrm{BA}^{+}$ & 1.47 & 18.90 & 8.91 & 6.58 & 2 \\
$\mathrm{SA}^{-} \nRightarrow \mathrm{BA}^{-}$ & 1.95 & 10.20 & 4.27 & 2.77 & 1 \\
$\mathrm{SA}^{+} \nRightarrow \mathrm{CA}^{+}$ & $25.28^{* * *}$ & 19.73 & 11.40 & 7.02 & 2 \\
$\mathrm{SA}^{-} \nRightarrow \mathrm{CA}^{-}$ & $4.03^{* *}$ & 9.15 & 3.88 & 2.97 & 1 \\
$\mathrm{BA}^{+} \nRightarrow \mathrm{SA}^{+}$ & 4.79 & 22.56 & 11.08 & 8.31 & 2 \\
$\mathrm{BA}^{-} \nRightarrow \mathrm{SA}^{-}$ & 0.16 & 9.38 & 4.35 & 3.16 & 1 \\
\hline
\end{tabular}

Notes: 1 . The symbol $B A \nRightarrow C A$ means that $B A$ does not cause $C A$ and $C V$ means critical value.

2. Cumulative positive $\left(\mathrm{BA}^{+}, \mathrm{CA}^{+}\right.$and $\mathrm{SA}^{+}$) and cumulative negative shocks (BA, $\mathrm{CA}^{-}$and $\mathrm{SA}$ ) are used.

3. Optimal lags were selected by Hatemi-J Criterion.

4. ${ }^{* * *}$ and ${ }^{* *}$ denote statistical significance at the $1 \%$ and $5 \%$ level of significance respectively

Based on these results, it is evident that only the null hypothesis that negative budget deficit shocks do not Granger-cause negative shocks in current account deficits can be rejected at the $5 \%$ significance level. The estimated parameter in 
this case is 0.89 , which means that a $1 \%$ permanent negative budget deficit shock will cause a $0.89 \%$ reduction in the current account deficit in the Turkish economy. We tested another relationship which is statistically significant between the savings gap and the current account deficit. The results show that the null hypothesis that negative savings gap shocks do not cause a negative shock in the current account deficit can be rejected at the $5 \%$ significance level. The estimated parameter is 0.53 . This means that a $1 \%$ permanent negative savings gap shock will cause a reduction in the current account deficit. The null hypothesis of no Granger causality cannot be rejected for the other two cases that deal with matching shocks. However, we also tested for combinations that consist of positive shocks. The results show that the null hypothesis that positive savings gap shocks do not cause a positive shock in the current account deficit can be rejected at the $1 \%$ significance level. The estimated parameter appears to be 0.08 . This means that a $1 \%$ permanent positive savings gap shock will cause a $0.08 \%$ increase in the current account deficit. The null hypothesis of no Granger causality cannot be rejected for the other three cases. Therefore, it is clear that the triple deficit hypothesis is valid in Turkey.

The most important recipe for the development of developing countries such as Turkey is to allocate a significant share of national income to investments. Domestic savings have an important role to play in financing investments. Investments cannot be increased due to the lower level of savings resulting from the insufficient national income levels of developing countries; the level of efficiency lags behind and the low level of national income continue. Ultimately, the insufficient savings in these countries fail to fully finance investments, and thus the issue of a budget deficit emerges. Turkey has an emerging economy and its level of national income is higher than other developing countries. Accordingly, the core problem for Turkey is not financial bottlenecks caused by insufficient domestic savings due to insufficient national income and related insufficient investments, but the fact that the ratio of domestic savings is very low. According to WDI, the domestic savings/GDP ratio of Turkey was $17 \%$ in 2011 but decreased to $12 \%$ in 2012. These figures are extremely low because the domestic savings/GDP ratios of both developed and developing countries are much higher than the ratio in Turkey. The report states that the 2012 total domestic savings/GDP ratios of developed countries such as Denmark, France, Germany, Italy, Holland, Spain and Sweden were 21.95, 17.58, 22.89, 18.85, 26.10, 20.67 and 24.92 respectively. The 2012 total domestic savings/GDP ratios of developing and emerging countries such as Argentina, Brazil, Chile, China, Israel, Mexico, India and Russia were 24.08, 16.20, $24.42,50.79,20.87,30.63,23.62,27.90$ and 33.27 respectively. Taking into consideration households in Turkey and the domestic saving trends of companies on the basis of these ratios, we can conclude that domestic savings in Turkey are really low.

Thus, policymakers should move towards policies that increase domestic savings. The leading policy is to reduce the amount of total credits. Reducing the total 
amount of credits is possible by using interest rate and monetary policy instruments such as required reserve ratios and rediscount ratios. Also, policymakers should give priority to these practices such as restructuring the banking sector with regard to credit arrangements and sectorial credits. In a country where the triple deficit hypothesis applies, increasing manufacturing and export credits can contribute to the national economy in the long run, although reducing the number of credits is important for increasing the ratio of national savings. Hence the types of credit that should be reduced are personal loans for residences and vehicles and consumer loans, which actually increase total demand. These conclusions are clearly illustrated for Turkey in the table summarized in Table A1. As seen in the table, the total credit volume in Turkey has increased significantly year by year. Although the share of commercial-corporate loans within total credits is high, the ratio of this credit type has declined year by year. Despite the increase in SME loans, the increase rate by years is not very high. The number of consumer loans is increasing and the ratio of these loans within total credits is significant. According to these conclusions, SME loans should be increased and consumer loans should be reduced in order to increase savings. In this context, the Banking Regulation and Supervision Agency (BRSA) have an important role to play. The BRSA should supervise the banking sector more strictly.

Besides domestic financial bottlenecks caused by the savings gap during the economic development process, foreign exchange bottlenecks caused by the foreign exchange deficit is also a serious problem. Achieving economic development primarily requires the importation of capital goods. However, foreign exchange earnings fall behind the level required for the target development ratio since the majority of foreign exchange incomes depend on exportation of products having lower added value, and thus the problem of a current account deficit emerges in the economy.

Therefore, policies that encourage the production of goods with high added value will prevent foreign exchange bottlenecks.

\section{Conclusion}

In this study, the validity was analyzed of the triple deficit hypothesis in Turkey between the years 1960 and 2012. First, the stationarity of positive and negative shocks related to the current account deficit, budget deficit and savings gap was tested. As a result of unit root tests, it was concluded that all the positive and negative shocks were I(1). Then, the causal relationship was analyzed with regard to the aforesaid shocks of variables by means of an asymmetric causality test. As a result of this test, a causal relationship between negative budget deficit shocks and the current account deficit was found. The estimated causal parameter in this case is 0.89 , which means that a $1 \%$ permanent negative budget deficit shock will cause a $0.89 \%$ reduction in the current account deficit in the Turkish economy. Apart from that, the null hypothesis that a negative savings gap shock does not Grangercause a negative shock in the current account deficit can be rejected. The 
estimated causal parameter appears to be 0.53 . This means that a $1 \%$ permanent negative savings gap shock will cause a $0.53 \%$ reduction in the current account deficit. The null hypothesis of no Granger causality cannot be rejected for the other two negative shocks. However, we tested for a combination that consists of positive shocks. The results show that the null hypothesis that positive savings gap shocks do not cause a positive shock in the current account deficit can be rejected at the $1 \%$ significance level. The estimated causal parameter is also 0.08 , which means a $1 \%$ permanent positive savings gap shocks will cause a $0.08 \%$ enhancement in the current account deficit in Turkey. The null hypothesis of no Granger causality cannot be rejected for the other three positive shocks. According to the causality results of positive and negative shocks, we conclude that the triple deficit hypothesis was valid in Turkey between the years 1960 and 2012.

The most important recipe for the development of developing countries such as Turkey is to allocate a significant share of national income to investments. Domestic savings have an important role to play in financing investments. Investments cannot be increased due to the lower level of savings resulting from the insufficient national income levels of developing countries; the level of efficiency lags behind and the low level of national income continue. Ultimately, the insufficient savings in these countries fail to fully finance investments, and thus the issue of a budget deficit emerges. In this context, increasing total savings is very important for ensuring a sustainable budget deficit and current deficit. Otherwise, the mechanism triggered by the savings deficit will create budget deficit and current account deficit problems. Therefore, policymakers should move towards policies that increase domestic savings. The leading policy is to reduce the amount of total credits. Reducing the total amount of credits is possible by using interest rate and monetary policy instruments such as required reserve ratios and rediscount ratios. Also, policymakers should give priority to these practices such as restructuring the banking sector with regard to credit arrangements and sectorial credits. In this context, the monetary policy authority and BRSA have important roles to play. The BRSA should supervise the banking sector more strictly.

On the other hand, while policy makers increase the gross domestic savings with various policies they need to conserve the economic growth and sustainability. Interest rate is important instrument for raising the saving rate. Moreover, interest rate is also more important in order to attract the foreign investment which finances the current account deficit. High interest rate can affect the economic growth negatively by reducing the consumer and investment spending and in parallel with increasing savings. In this context, saving paradox can occur in economy. Therefore, reduction of expenditures should be through consumer spending for decreasing current account deficit. This implantation reduces the consumer spending in short run and makes significant contribution to decreasing current account deficit by increasing investments in long run. 
The most important point here is that although Turkish government has the power to establish the budget and investment-savings balances which form the internal economic balance of a country, the central bank, as the monetary policy enforcer, has the power to use instruments such as interest, loan, and foreign exchange rates. The coordination of institutions is very important while implementing economic policy, including finance and monetary policy. The goals of an authority assigned to conduct financial policy and those of an authority assigned to implement monetary policy might conflict, or the instruments used might prevent the goals of the other authority from being achieved, even though these two authorities may have similar goals. Hence, the authorities responsible for financial and monetary policies should coordinate their actions in order to successfully implement economic policy.

\section{References}

Abell, J.D. (1990). "Twin Deficits During the 1980s: An Empirical Investigation." Journal of Macroeconomics 12(1): 81-96.

http://dx.doi.org/10.1016/0164-0704(90)90057-H

Acaravci, A. \& Ozturk, I. (2008). "Twin Deficits Phenomenon: Empirical Evidence from the ARDL Bound Test Approach for Turkey." Bulletin of Statistics and Economics 2:57-64. Akbostancl, E. \& Tunç, G.i. (2002). "Turkish Twin Deficits: An Error Correction Model of Trade Balance." ERC Working Papers.

Aksu, H. \& Başar, S. (2005). "ikiz Açıklar Hipotezi'nin Türkiye Açısından Araştırılması." Iktisat, Işletme ve Finans Dergisi 20(234): 109-114.

Aksu, H. \& Başar, S. (2009). "Türkiye için İkiz Açıklar Hipotezinin Tahmini: Bir Sınır Testi Yaklaşımı." Ankara Üniversitesi Siyasal Bilgiler Fakültesi Dergisi 64(4): 1-14.

Alkswani, A.M. (2000). "The Twin Deficit Phenomenon in Petroleum Economy: Evidence from Saudi Arabia", Seventh Annual Conference, Economic Research Forum, Amman.

Altıntaş, H. \& Taban, S. (2011). "Twin Deficit Problem and Feldstein-Horioka Hypothesis in Turkey: ARDL Bound Testing Approach and Investigation of Causality." International Research Journal of Finance and Economics 74: 30-45.

Ata, A.Y. \& Yücel, F. (2003)."Eş-bütünleşme ve Nedensellik Testleri Altında İkiz Açıklar Hipotezi: Türkiye Uygulaması." Çukurova Üniversitesi SBE Dergisi 12(12): 97-110.

Ay, A., Karaçor, Z., Mucuk, M. \& Erdoğan, S. (2004). "Bütçe Açı̆̆ı-Cari İşlemler Açığı Arasındaki İlişki: Türkiye Örneği (1992-2003)." Selçuk Üniversitesi Sosyal Bilimler Enstitüsü Dergisi 12: 75-82.

Bachman, D.D.(1992). "Why is the U.S. Current Account Deficit so Large? Evidence from Vector Auto regressions." Southern Economic Journal 59(2): 232-240. http://dx.doi.org/10.2307/1060527

Bahmani-Oskooee, M. (1992). "What are the Long-Run Determinants of the U.S TradeBalance?" Journal of Post Keynesian Economics 15(1): 85-97.

Barro, R.J. (1989). "The Ricardian Approachto Budget Deficits." The Journal of Economic Perspectives 3(2): 37-54.

http://dx.doi.org/10.1257/jep.3.2.37

Baxter, M. \& Crucini, M.J. (1993). "Explaining saving - investment correlations." The American Economic Review 83(3): 416-436.

EJBE 2014, 7 (14)

Page | 149 
Bernheim, B.D. (1988). "Budget Deficits and the Balance of Trade." NBER Working Paper, No.10935.

Bilgili, E. \& Bilgili, F. (1998). "Bütçe Açı̆̆ının Cari İşlemler Dengesi Üzerindeki Etkileri: Teori ve Uygulama." iktisat Iş̧letme ve Finans, Mayıs Eki, 13(146):4-16.

Biswas, B., Tribedy, G. \& Saunders, P. (1992)."Further Analysis of the Twin Deficits." Contemporary Economic Policy 10(1): 104-107.

http://dx.doi.org/10.1111/j.1465-7287.1992.tb00217.x

Boucher, J.L. (1991). "The U.S. Current Account: A Long and Short Run Empirical Perspective." Southern Economic Journal 58(1): 93-111.

http://dx.doi.org/10.2307/1060036

Cooper, R.N.(2001). “Is the U.S. Current Account Deficit Sustainable? Will it be Sustained?” Brookings Papers on Economic Activity 2001(1): 217-226. http://dx.doi.org/10.1353/eca.2001.0002

Corsetti, G. \& Müller, G.J. (2006). "Twin Deficits: Squaring Theory, Evidence and Common Sense." Economic Policy 21(48): 597-638.

http://dx.doi.org/10.1111/j.1468-0327.2006.00167.x

Darrat, A.F. (1988). “Have Large Budget Deficits Caused Rising Trade Deficits?"Southern Economic Journal 54(4): 870-887.

http://dx.doi.org/10.2307/1059523

Dewald, W.G. \& Ulan, M. (1990). "The Twin-Deficit Illusion." Cato Journal 9(3):689-707.

Dibooglu, S. (1997). "Accounting for US Current Account Deficits: An Empirical Investigation." Applied Economics Taylor and Francis Journals 29(6): 787-793.

Domenech, R., Taguas D. \& Varela, J. (2000)."The Effects of Budget Deficit on National Saving in the OECD." Economics Letters 69(3): 377-383.

http://dx.doi.org/10.1016/S0165-1765(00)00316-5

Dooley, M., Frankel J. \& Mathieson, D.J. (1987).“International Capital Mobility: What Do Saving-Investment Correlations Tell Us?” IMF Staff Papers 34(3): 503-530. http://dx.doi.org/10.2307/3867094

Egwaikhide, F.O. (1999). "Effects of Budget Deficit on Trade Balance in Nigeria: A Simulation Exercise." African Development Review 11(2): 265-289. http://dx.doi.org/10.1111/1467-8268.00011

Eğilmez, M. (2006). “Üçüz açık." Radikal, Retrieved from http://www.radikal.com.tr/haber.php?haberno=188787

Eisner, R. (1994). "National Saving and Budget Deficits." The Review of Economics and Statistics 76(1): 181-186.

http://dx.doi.org/10.2307/2109836

Elwell, C.K. (2007). "The U.S. Trade Deficit: Causes, Consequences and Cures", CRS Report for Congress.

Elwell, C.K. (2010). "The U.S. Trade Deficit: Causes, Consequences and Policy Options", CRS Report for Congress.

Enders, W. \& Lee, B.-S. (1990).“Current Account and Budget Deficits: Twins or Distant Cousins." The Review of Economics and Statistics 72(3): 373-381. http://dx.doi.org/10.2307/2109344 
Erceg, C.J., Guerrieri, L. \& Gust, C. (2005). "Expansionary Fiscal Shocks and the Trade Deficit." International Finance Discussion Papers, No. 825, Washington.

Erdinç, Z. (2008). “ikiz Açıklar Hipotezinin Türkiye'de 1950-2005 Yılları Arasında Eşbütünleşme Analizi ve Granger Nedensellik Testi ile İncelenmesi." Anadolu Üniversitesi Sosyal Bilimler Dergisi 8(1): 209-222.

Feldstein, M. (1992). “The Budget and Trade Deficits aren't Really Twins.” NBER Working Paper, No. 3966.

http://dx.doi.org/10.3386/w3966

Feldstein, M. (2008). "Resolving the Global Imbalance: The Dollar and the U.S. Saving Rate."Journal of Economic Perspectives American Economic Association 22(3): 113-125. http://dx.doi.org/10.1257/jep.22.3.113

Fidrmuc, J. (2003). "The Feldstein-Horioka Puzzle and Twin Deficits in Selected Countries." $\begin{array}{llll}\text { Economics of } & \text { Planning } & \text { 36(2): } & \text { 135-152. }\end{array}$ http://dx.doi.org/10.1023/B:ECOP.0000012256.88112.c2

Fischer, S. \& Easterly, W. (1990). "The Economics of the Government Budget Constraint." The World Bank Research Observer 5(2): 127-142.

http://dx.doi.org/10.1093/wbro/5.2.127

Freund, C. (2005). "Current Account Adjustment in Industrial Countries." Journal of International Money and Finance 24(8): 1278-1298.

http://dx.doi.org/10.1016/j.jimonfin.2005.08.014

Froyen, R.T. (1999). Macro Economics Theories and Policies. $16^{\text {th }}$ ed., New Gersey: Prentice Hall Inc.

Gale, W.G. \& Orszag, P.R. (2003). "Economic Effects of Sustained Budget Deficits." National Tax Journal 56(3): 463-485.

Ganchev, G.T.(2010)."The Twin Deficit Hypothesis: The Case of Bulgaria." Financial Theory and Practice 34(4): 357-377.

Gruber, J.W. \& Kamin, S.B. (2007). "Explaining the Global Pattern of Current Account Imbalances." Journal of International Money and Finance 26(4): 500-522. http://dx.doi.org/10.1016/j.jimonfin.2007.03.003

Hacker, R.S. \& Hatemi-J, A.(2006). "Tests for Causality Between Integrated Variables Using Asymptotic and Bootstrap Distributions: Theory and Application." Applied Economics 38(13): 1489-1500.

http://dx.doi.org/10.1080/00036840500405763

Hacker, R.S. \& Hatemi-J, A. (2010). HHcte: GAUSS Module to Apply a Bootstrap Test for Causality With Endogenous Lag Order. Statistical Software Components G00012. Boston College Department of Economics

Hakkio, C.S. (1995). "The U.S. CurrentAccount: The Other Deficit." Economic Review 80:1124.

Hatemi-J, A. \& Uddin, G.S. (2012). "Is the Causal Nexusof Energy Utilization and Economic Growth Asymmetric in the US?" Economic Systems 36(3): 461-469. http://dx.doi.org/10.1016/j.ecosys.2011.10.005

Hatemi-J, A. (2012). "Asymmetric Causality Tests with an Application." Empirical Economics 43(1):447-456.

http://dx.doi.org/10.1007/s00181-011-0484-x 
Hatsopoulos, G.N., Krugman, P.R. \& Summers, L.H. (1988). “U.S. Competitiveness: Beyond the Trade Deficit." 241(4863): Science 299-307. http://dx.doi.org/10.1126/science.241.4863.299

Higgins, M. \& Klitgaard, T. (1998). "Viewing the Current Account Deficit as a Capital Inflow." Current Issues in Economics and Finance 4(13): 1-6.

Holmes, M.J. (2011). "Threshold Cointegration and the Short-Run Dynamics of Twin Deficit Behaviour." Research in Economics 65(3): 271-277. http://dx.doi.org/10.1016/j.rie.2010.11.004

Hubbard, R.G. (2006). "The U.S. Current Account Deficit and Public Policy." Journal of Policy Modeling 28(6): 665-671.

http://dx.doi.org/10.1016/j.jpolmod.2006.06.006

Iram, M.P.S., Shadid, A.,Mahpara, S. \& Fazli, R. (2011). “Old Wine in New Bottles: Testing the Keynesian Preposition of Twin Deficit in Case of Pakistan." International Journal of Business and Social Science 2(5): 209213.

Ito, H. (2009). "U.S. Current Account Debate with Japan Then, with China Now." Journal of Asian Economics 20(3): 294-313.

http://dx.doi.org/10.1016/j.asieco.2009.02.006

Kalou, S. \& Paleologou, S.-M. (2012). "The Twin Deficits Hypothesis: Revisiting an EMU Country." Journal of Policy Modeling 34(2): 230-241. http://dx.doi.org/10.1016/j.jpolmod.2011.06.002

Kaufmann, S., Winckler, G. \& Scharler, J. (2002).“The Austrian Current Account Deficit: Driven by Twin Deficits or by Intertemporal Expenditure Allocation?" Empirical Economics 27(3): 529-542.

http://dx.doi.org/10.1007/s001810100094

Kearney, C. \& Monadjemi, M. (1990). "Fiscal Policy and Current Account Performance: International Evidence on the Twin Deficits." Journal of Macroeconomics 12:197-219. http://dx.doi.org/10.1016/0164-0704(90)90029-A

Khalid, A.M. \& Guan, T.W.(1999). "Causality Tests of Budget and Current Account Deficits: Cross-Country Comparisons." Empirical Economics 24(3): 389-402. http://dx.doi.org/10.1007/s001810050062

Kim, K.-H. (1995). "On the Long-Run Determinants of the U.S. Trade Balance: A Comment." Journal of Post Keynesian Economics 17(3): 447-455.

Kim, S. \& Roubini, N.(2008). "Twin Deficit or Twin Divergence? Fiscal Policy, Current Account and Real Exchange Rate in the U.S." Journal of International Economics 74(2): 362-383. http://dx.doi.org/10.1016/j.jinteco.2007.05.012

Kouassi, E., Mougoue, M. \& Kymn, K.O. (2004). "Causality Tests of the Relationship Between The Twin Deficits." Empirical Economics 29(3): 503-525.

http://dx.doi.org/10.1007/s00181-003-0181-5

Kuijs, L. (2006). “How will China's Saving-Investment Balance Evolve?” World Bank Policy Research Working Paper, No.3958.

Kulkarni, K.G. \& Erickson, E.L. (2001). "Twin Deficit Revisited: Evidence from India, Pakistan and Mexico." Journal of Applied Business Research 17(2): 97-104.

Kuştepeli, Y.R. (2001). "An Empirical Investigation of the Feldstein Chain for Turkey.” Dokuz Eylül Üniversitesi İşletme Fakültesi Dergisi 2(1): 99-108. 
Kutlar, A. \& Şimşek, M. (2001). "Türkiye'de Bütçe Açıklarının Dış Ticaret Açıklarına Etkileri, Ekonometrik Bir Yaklaşım: 1984(4)-2000(2)." Dokuz Eylül Üniversitesi iiBF Dergisi 16(1): 1-13. Labonte, M. (2005). "Is the U.S. Trade Deficit Caused by a Global Saving Glut?", CRS Report for Congress.

Latif-Zaman, N. \& Da Costa, M.N. (1990). "The Budget Deficit and the Trade Deficit: Insights Into This Relationship." Eastern Economic Journal 16(4): 349-354.

Lau, E. \& Tang, T.C. (2009). "Twin Deficits in Cambodia: Are There Reasons for Concern? An Empirical Study." Monash University Working Paper, No. 11/09, Australia.

Leachman, L.L. \&Francis, B.(2002)."Twin Deficits: Apparition or Reality?”Applied Economics 34(9): 1121-1132.

http://dx.doi.org/10.1080/00036840110069976

Lipsey, R.G., Courant, P.N. \& Ragan, C.T.S. (1999). Economics. $11^{\text {th }}$ ed., United States: The Addison-Wesley Publishing Company.

Mann, C.L. (2002). "Perspectives on the U.S. Current Account Deficit and Sustainability."

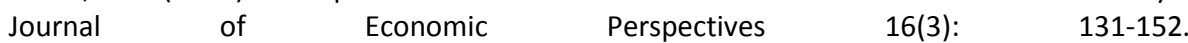
http://dx.doi.org/10.1257/089533002760278758

Milesi-Ferretti, G.M. \& Razin, A. (1996). "Sustainability of Persistent Current Account Deficits." International Journal of Finance Economics 1(3): 161-181. http://dx.doi.org/10.1002/(SICI)1099-1158(199607)1:3<161::AID-IJFE19>3.0.CO;2-W

Miller, S.M. \& Russek, F.S. (1989). "Are the Twin Deficits Really Related?" Contemporary Economic Policy 7(4): 91-115.

http://dx.doi.org/10.1111/j.1465-7287.1989.tb00577.x

Mukhtar, T., Zakaria, M. \& Ahmed, M. (2007). "An Empirical Investigation for the Twin Deficits Hypothesis in Pakistan." Journal of Economic Cooperation 28(4): 63-80.

Pattichis, C. (2004). "Budget and Trade Deficits in Lebanon." Applied Economics Letters 11(2): 105-108.

http://dx.doi.org/10.1080/1350485042000200204

Penati, A. \& Dooley, M. (1984). “Current Account Imbalances and Capital Formation in Industrial Countries: 1949-1981." IMF Staff Papers 31(1): 1-24. http://dx.doi.org/10.2307/3866976

Piersanti, G. (2000). "Current Account Dynamics and Expected Future Budget Deficits: Some International Evidence. "Journal of International Money and Finance 19(2): 255-271. http://dx.doi.org/10.1016/S0261-5606(00)00004-8

Ratha, A., (2012). "Twin Deficits or Distant Cousins? Evidence from India." South Asia Economic Journal 13(1):51-68.

http://dx.doi.org/10.1177/139156141101300103

Rosensweig, J.A. \& Tallman, E.W. (1993). "Fiscal Policy and Trade Adjustment: Are the Deficits Really Twins?" Economic Inquiry 31(4): 580-594.

http://dx.doi.org/10.1111/j.1465-7295.1993.tb00892.x

Roubini, N. (1988). "Current Account and Budget Deficits in an Intertemporal Model of Consumption and Taxation Smoothing: A Solution to the Feldstein- Horioka Puzzle?" NBER Working Paper, No. 2773, Camberidge, MA.

Salvatore, D. (2006). "Twin Deficits in the G-7 Countries and Global Structural Imbalances." Journal of Policy Modeling 28(6): 701-712.

http://dx.doi.org/10.1016/j.jpolmod.2006.06.003

EJBE 2014, 7 (14)

Page | 153 
Szakolczai, G. (2006). "The Triple Deficit of Hungary." Hungarian Statistical Review 84(10): 40-62.

Tallman, E.W. \& Rosensweig, J.A. (1991). "Investigating US Government and Trade Deficits." Economic Review (Federal Reserve Bank of Atlanta) 76(3): 1-11.

Toda, H.Y. \& Yamamoto, T. (1995). "Statistical Inference in Vector Auto regressions with Possibly Integrated Processes." Journal of Econometrics 66(1-2): 225-250. http://dx.doi.org/10.1016/0304-4076(94)01616-8

Trachanas, E. \& Katrakilidis, C. (2013). "The Dynamic Linkages of Fiscal and Current Account Deficits: New Evidence from Five Highly Indebted European Countries Accounting for Regime Shifts and Asymmetries". Economic Modelling 31: 502-510. http://dx.doi.org/10.1016/j.econmod.2012.12.026

Utkulu, U.(2003). "Türkiye'de Bütçe Açıkları ve Dış Ticaret Açıkları Gerçekten İkiz Mi? Koentegrasyon ve Nedensellik Bulguları." Dokuz Eylül Üniversitesi IïB Dergisi 18(1): 45-61.

Uz, I. (2010). "Determinants of Current Account: The Relation Between Internal and External Balances in Turkey." Applied Econometrics and International Development 10(2): 115-126.

Vamvoukas, G.A. (1999). "The Twin Deficits Phenomenon: Evidence from Greece. "Applied Economics 31(9):1093-1100.

http://dx.doi.org/10.1080/000368499323571

Winner, L.E. (1993). "The Relationship of the Current Account Balance and the Budget Balance." American Economist 37(2): 78-84.

Yaldız, E. (2006). İkiz Açık Hipotezi ve Türkiye. İzmir İktisat Kongresi Araştırma Merkezi Bilimsel Çalışma Raporları Serisi 1, İzmir.

Zaidi, I.M. (1985). "Saving, Investment, Fiscal Deficits and the External Indebtedness of Developing Countries." World Development 13(5): 573-588.

http://dx.doi.org/10.1016/0305-750X(85)90022-1

Zamanzadeh, A. \& Mehrara, M. (2011). "Testing Twin Deficits Hypothesis in Iran." Interdisciplinary Journal of Research in Business 1(9): 7-11.

Zengin,A. (2000). “ikiz Açıklar Hipotezi (Türkiye Uygulaması).” Ekonomik Yaklaşım 11(39): 3767.

Zietz, J. \& Pemberton, D.K. (1990). "The U.S. Budget and Trade Deficits: A Simultaneous Equation Model." Southern Economic Journal 57(1): 23-34.

\section{Appendix}

Table A1.The Distribution of Total Credit with Regard to Types in Turkey

\begin{tabular}{cccccccc}
\hline & \multicolumn{2}{c}{$\begin{array}{c}\text { Commercial- } \\
\text { corporate loans }\end{array}$} & SME loans & & Personal loans & \multicolumn{2}{c}{$\begin{array}{c}\text { Total credit } \\
\text { volume }\end{array}$} \\
\cline { 2 - 8 } Years & Billion TL & (\%) & Billion TL & (\%) & Billion TL & (\%) & Billion TL \\
\hline 2008 & 165.7 & 45.1 & 84.6 & 23.0 & 117.1 & 31.9 & 367.4 \\
2009 & 179.4 & 45.7 & 83.3 & 21.2 & 129.9 & 33.1 & 392.6 \\
2010 & 227.8 & 43.3 & 125.5 & 23.9 & 172.6 & 32.8 & 525.9 \\
2011 & 296.2 & 43.4 & 162.8 & 23.8 & 223.9 & 32.8 & 682.9 \\
2012 & 330.4 & 41.6 & 198.4 & 25.0 & 165.9 & 33.5 & 794.8 \\
\hline
\end{tabular}

